\title{
A Study of Three Mosaics Donated to the Archaeological Museum D. Diogo de Sousa in Braga (Portugal)
}

\author{
Braga'daki (Portekiz) D. Diogo de Sousa Arkeoloji Müzesi'ne Bağışlanan \\ Üç Mozaik Üzerine Bir Çalışma
}

\author{
Fátima ABRAÇOS* - Licínia WRENCH** - Cátia MOURÃO***
}

(Received 04 February 2020, accepted after revision 03 August 2020)

\begin{abstract}
Three mosaics from a private collection were donated to D. Diogo de Sousa Archaeological Museum in Braga. One of them presents a hunting scene; another shows vine scrolls with leaves and grapes; the third presents a mythological scene where Pelops and Hippodamia are represented.

In this study, we describe these mosaics and we follow their path to integrate the MDDS collection in order to provide researchers with their study and to allow their use by all types of public. As we know, the mosaics' musealization must be made within the context to better understand the past, but we can't disprove all mosaics surveys, because due to these actions that are promptly condemned today, except when demanded for conservation and heritage preservation purposes, we can study and enjoy the beauty of many of these pieces.
\end{abstract}

Keywords: Roman mosaic, museum collections, galleries, safeguard, conservation and restoration.

Öz

Braga'daki D. Diogo de Sousa Arkeoloji Müzesi’ne özel bir koleksiyondan üç mozaik bağışlanmıştır. Bunlardan ilki bir av sahnesini; bir diğeri yaprak ve üzümleri olan bir asma dalın temsil eder. Üçüncüsü ise Pelops ve Hippodamia'nın betimlendiği mitolojik bir sahnedir.

Çalışmada, bu mozaikleri tanımlayacağız ve araştırmacılara çalışmalarında yardımcı olmak ve her türlü kamu unsuru tarafindan kullanılmalarına izin vermek için MDDS koleksiyonunu entegre etme yolunu takip edeceğiz. Bildiğimiz gibi, geçmişin daha iyi anlaşılması için mozaiklerin müzeleştirilmesi kontekst dahilinde yapılmalıdır. Ancak tüm mozaik araştırmalarını çürütemeyiz. Çünkü konservasyon ve mirasın korunması amacıyla talep edilenler dışında bugün eleştirilen bu çalışmalar sayesinde söz konusu parçaların çoğunun güzelliğini inceleyebilir ve tadını çıkarabiliriz.

Anahtar Kelimeler: Roma mozaiği, müze koleksiyonlarl, galeriler, korumak, koruma ve restorasyon.

\footnotetext{
* Maria de Fátima Abraços, Investigadora do Instituto de História da Arte - Faculdade de Ciências Sociais e Humanas, Universidade Nova de Lisboa/ Av. de Berna, 26-C/1069-061 Lisboa, Portugal. (iD) https://orcid.org/0000-0003-0997-9553. E-mail: maria.abracos1951@gmail.com

** Licínia Wrench, Investigadora do Instituto de História da Arte - Faculdade de Ciências Sociais e Humanas, Universidade Nova de Lisboa/Av. De Berna, 26-C/1069-061 Lisboa, Portugal. (iD https://orcid.org/0000-0002-5780-2018. E-mail: wrench.licinia@gmail.com

*** Cátia Mourão, Instituto de História da Arte, Faculdade de Ciências Sociais e Humanas, Universidade Nova de Lisboa/Av. de Berna, 26-C/ 1069-061/ Lisboa, Portugal. (iD https://orcid.org/0000-0002-2359-7327.E-mail: cmourao@fcsh.unl.pt
} 


\section{I - Decontextualized Roman Mosaics. Presentation of Some Examples in Museum Collections}

In Portugal, more than thirty museums have in their collections mosaic fragments, whose origin we are not always able to trace or ascertain (Abraços 2008). Therefore, we believe that musealization should be done within the archaeological context in order to understand the past. However, we must not disapprove of all the mosaic surveys that were carried out over time, regardless of their more or less reasonable justifications. It is due to these actions, which we occasionally condemn, except when they are supported by reasons of heritage conservation and protection, that today we are able to study and enjoy the beauty of many of these pieces, while making them available to all types of public. The most recent case in Portugal concerns the mosaics donated to the D. Diogo de Sousa Museum, in Braga, which we will discuss in this text.

At the reserve of the National Museum of Archaeology, in Lisbon, and in many other foreign museums, there are mosaics from the Near East. These pieces of heritage have been decontextualized due to their commercialization, an illegal trade common in this region. However, most of the heritage in this territory has been protected and preserved outside their place of origin and it has circulated under the terms of cultural exchange and cooperation between states.

Five fragments belonging to a mosaic pavement from Belkıs, in Zeugma, currently in the territory of modern Turkey, were deposited at the reserve of the National Museum of Archaeology in Lisbon. This mosaic pavement featured a central panel with the god Neptune, as a representation of the Mediterranean Sea, surrounded by the Roman Provinces. It was broken down in approximately forty fragments and divided by more than a dozen owners. The fragments existing at the reserve of the National Museum of Archaeology were purchased by the Consul of Portugal, in Aleppo, and sent to the National Museum of Ancient Art in Lisbon, where they remained until 1951, when they became part of the collection of the National Museum of Archaeology, in the same city (Lancha 1985: 155-176).

\section{II - About the Donation of Mosaics Offered to the Archaeological Museum D. Diogo de Sousa, in Braga}

In 2018, we found out that three mosaics were donated to the D. Diogo de Sousa Museum by the couple Hans-Peter Buehler and Marion Buehler-Brockhaus: one of the mosaics displayed the figures of Hippodamia and Pelops, another had the representation of a hunting scene and the third was decorated with a vine-scroll.

These private collectors met in 1959, in Stuttgart, in southern Germany. He was the son of a family of art dealers. Literature, music and art always had a predominant role in the lives of this couple. Both studied Art History and Archaeology. They preferred to travel to countries with nuclei of Greek and Roman culture. Hans-Peter and Marion possessed a fascination about the ancient world, but the destiny of their lives took them in a different direction: soon after they completed their studies, they entered the family's company, founded in 1904, in Stuttgart. In 1975, they moved to Munich where they lived for more than 30 years. For professional reasons, they travelled to London, Paris, New York and several other cities in Europe and the United States to research collections of art galleries, antique stores, auction houses and major art fairs, while visiting the archaeology departments of the museums (in Arqueologia. Bruehler-Brockhaus Collection, Museum of Setúbal. Convent of Jesus. Setúbal 2015: 11-16). 
In the summer of 1994, they travelled along Portugal, from Faro to Porto, stopping at $\mathrm{S}$. Cucufate and Conímbriga. In the following year, they visited the Vicentine Coast up to Tróia and, in 2006, they moved permanently from Munich to Setúbal to settle and establish a foundation there, something they succeeded to do in 2008. The city has benefited greatly from the financial support of this Foundation.

The couple proposed to several museums the possibility of donating some of the pieces of their collection: Greek glass and ceramic containers, marble statues and Roman mosaics. However, they demanded the collection not to be divided in different rooms, or mixed with pieces from other collections. The director of the Regional Museum of Archaeology D. Diogo de Sousa in Braga, Dra. Isabel Cunha Silva, showed interest in displaying the collection and agreed to provide a room. As a result, in 2018, the couple and the Director signed the donation act. In February, the Museum started preparing the exhibition with 200 pieces representing the five decades of travels done by the couple to several countries. The room reserved by the Museum for the exhibition displays Greek containers from around $700 \mathrm{BC}$ : some in glass, collected in southern Italy, others in ceramics, figurative, found in tombs. Some Roman sculptures from the $1^{\text {st }}$ and $2^{\text {nd }}$ centuries $\mathrm{AD}$ are also on display, including a female figure on a throne, in marble, collected in Turkey, and three Roman mosaics.

\section{III - Presentation of the Mosaics}

\section{III - 1. The Mosaic of Hippodamia and Pelops. The Representations of Pothos}

Figure 1

Marriage of Hippodamia and Pelops (Opus tessellatum - stone tesserae, including marble, and glass) (H. 201 $\mathrm{cm} / \mathrm{W} .209 \mathrm{~cm})$. (C) AFMDDS.

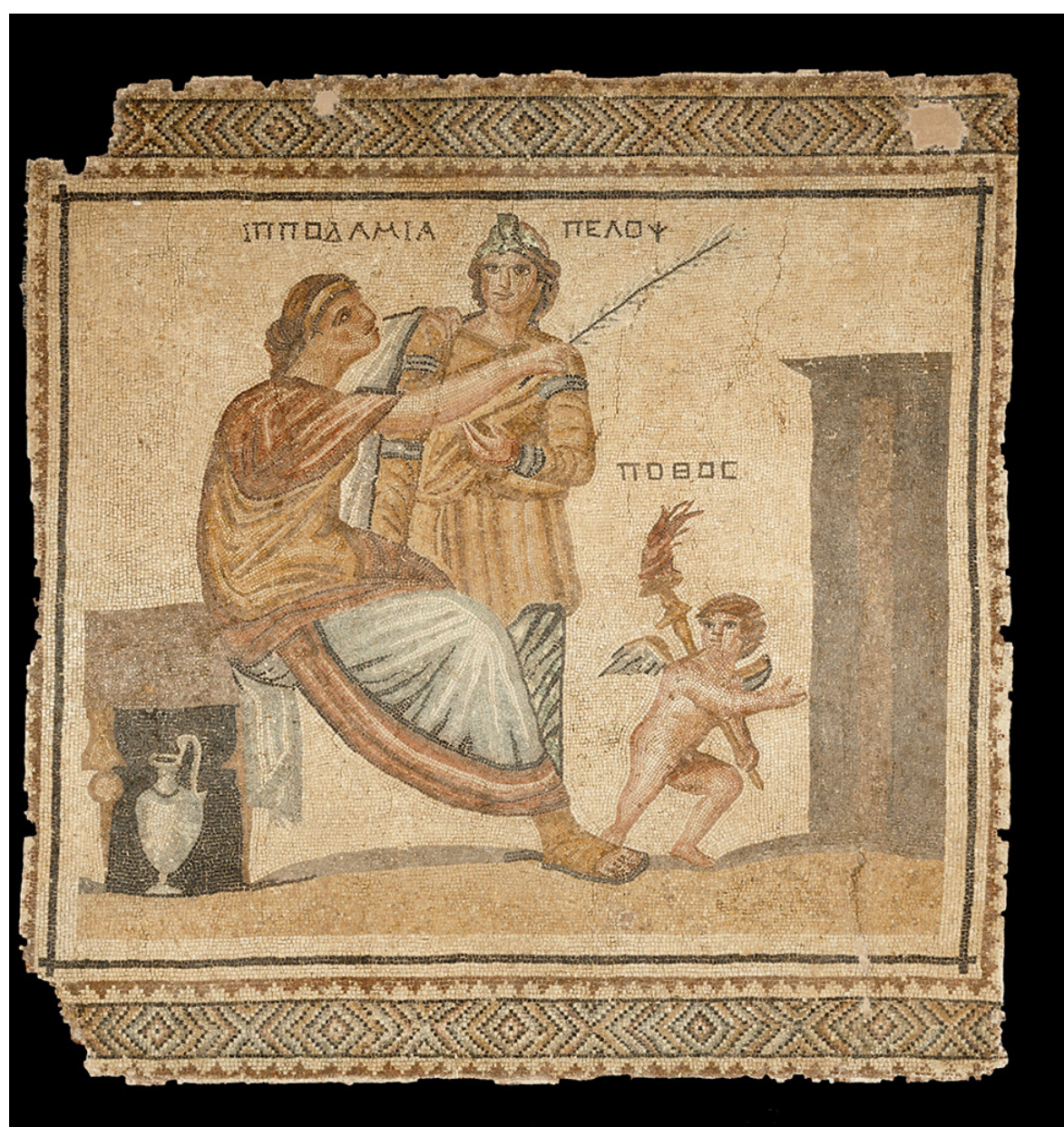


The mosaic features a mythological scene depicting the marriage of Hippodamia and Pelops ${ }^{1}$, prince and son of Tantalus, king of Anatolia. Pelops is standing in the centre of the scene, dressed in a yellow tunic and green pants, looking straight ahead. The Phrygian cap shows the strands of hair that appear on each

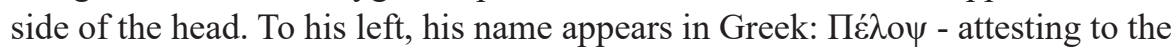
Hellenic influence of the production of this mosaic, possibly in the Middle East (perhaps even in Turkey).

Hippodamia, daughter of Oenomaus, king of Pisa, in the Peloponnese, is seated in front of Pelops, on a simple wooden seat, without a backrest or arms, under which appears a lekithos (Greek jar, pear-shaped, with a single handle). The princess holds a palm leaf in her right hand and wears a green and red tunic and cloak. A golden headband supports her long hair and her name appears in Greek, on her head: I $\pi \pi 0 \delta \alpha ́ \mu 1 \alpha$.

According to one version of the myth, Pothos ( Пó $\theta$ o $\xi$ ) is the son of Zephyrus and Iris and belongs to Aphrodite's entourage. Here, he is portrayed as one of the erotes (winged child) carrying the torch of Himeneus; he stands in front of the couple and points to a door. This figure was deliberately chosen to remember the couple's dramatic future. The Greeks used the term pothos to refer to the type of desire that leads to death. It is the desire for what is absent, a desire that causes suffering, as it can never be fulfilled. The term is associated with both the semantic field of love and mourning.

The scene is framed by rows of black tesserae and a decoration based on triangles, at the top and at the bottom two rows of serrated saw-tooth pattern (Décor I: $10 \mathrm{~g}$ ) frame a band of rainbow pattern superposed chevrons (Décor I: $7 \mathrm{~g}$ ) with a polychrome treatment, in gradation, repeated alternately in parallel series, forming squares over the vertex.

Pothos, with the flaming torch resting on his right shoulder, points to the building where the famous race between Pelops and Oenomaus will take place. He indicates the way to the union with the young Hippodamia, who, seated, raises her palm to the winners, indicating the task that the young suitor must perform in order to gain her love: the triumph over Oenomaus in a car race.

To comprehend the scene depicted on this mosaic, Luz Neira (Neira Jiménez 2018: 149-154) analyses ancient literary sources and Pothos' images in two other mosaics. In the mosaic representing Selene and Endymion, Pothos points with his finger at the sleeping Endymion, whose deep and eternal sleep renders carnal union impossible, making Selene miss and suffer for her "absent" love. In the mosaic of Dionysus and Ariadne, from Philippopolis (present-day Shahba), dated from the second quarter of the $4^{\text {th }}$ century AD, preserved at the Shahba Museum, in Syria, Pothos, instead of personifying absent love, is between the couple, carrying a flaming torch that normally symbolizes marriage, the union between lovers, according to the myth of the nuptials.

1 This mosaic belonged to the collection of the Jaume Bagot Gallery, located at the centre of Barcelona and dedicated to the sale of ancient art, since 2005. According to the staff of this gallery, its main objective is to offer works of art, both ancient and original, guarantee their authenticity and maximum quality, while respecting the laws for the protection of national, foreign and UNESCO heritage. 
Figure 2a

Pothos' representation on the mosaic of Selene and Endymion (Neira Jiménez 2018: 152 fig. 2).

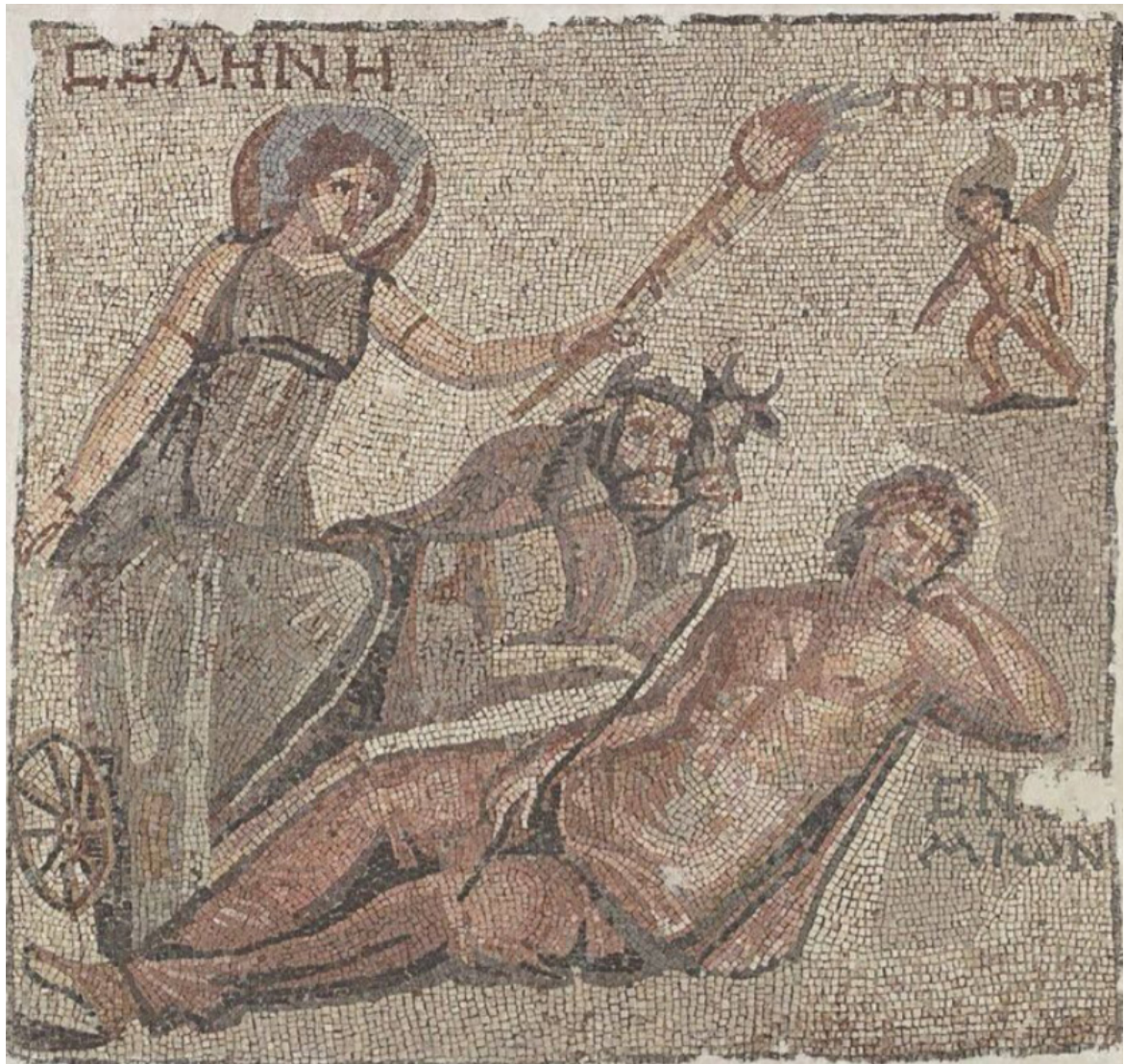

Figure $2 b$

Pothos' representation on the mosaic of Dionysus and Ariadne, Philippopolis (Neira Jiménez 2018:

153 fig. 3).

Figure 2c

The marriage of Hippodamia and Pelops on the mosaic of the Shahba Museum, Syria (Balty 1995: 340 pl.VIII fig. 2).

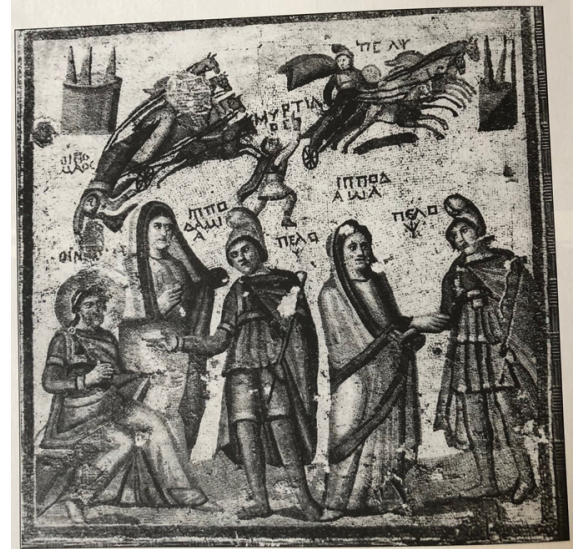

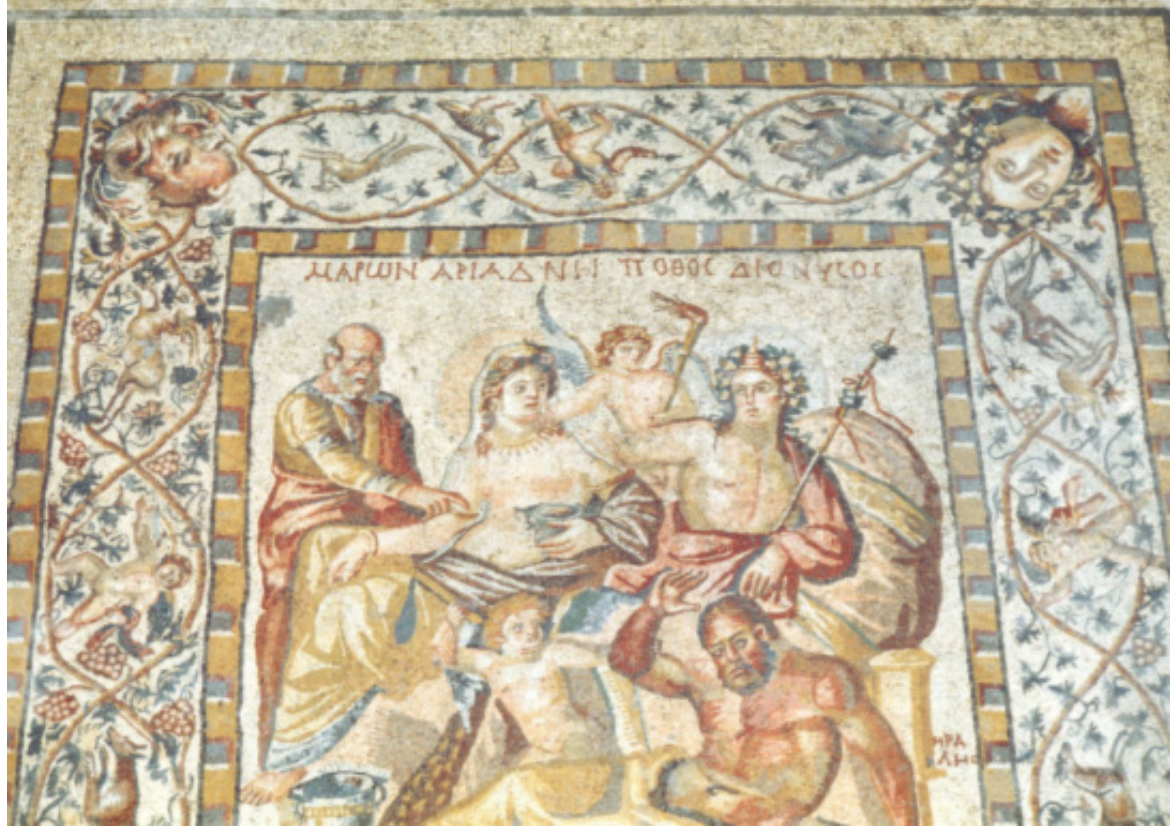

Regarding another mosaic of Philippopolis, at the Shahba Museum (Fig. 2c), with the representation of Hippodamia and Pelops, Janine Balty (Balty 1995: $65,340 \mathrm{pl}$. VIII fig. 2) considers it a late version of the legend, depicting on the top of the mosaic the race in which Pelops triumphed over Oenomaus. Myrtilus, the traitor to Oenomaus, is present between the two teams. This late version of the legend is reported by Apolodoro or Pausanias, since neither Píndaro nor the pediment of Olympia knew Myrtilus. The representation of the myth of Pelops, which appears in a small number of sarcophagi of the $3^{\text {rd }}$ century AD, was not 
seen in mosaic until this date; due to this, the pavement of Shahba is particularly important and it can be dated to the end of the $3^{\text {rd }}$ century, beginning of the $4^{\text {th }}$ century AD.

\section{III - 2. The Mosaic with Hunting Scene (Chase)}

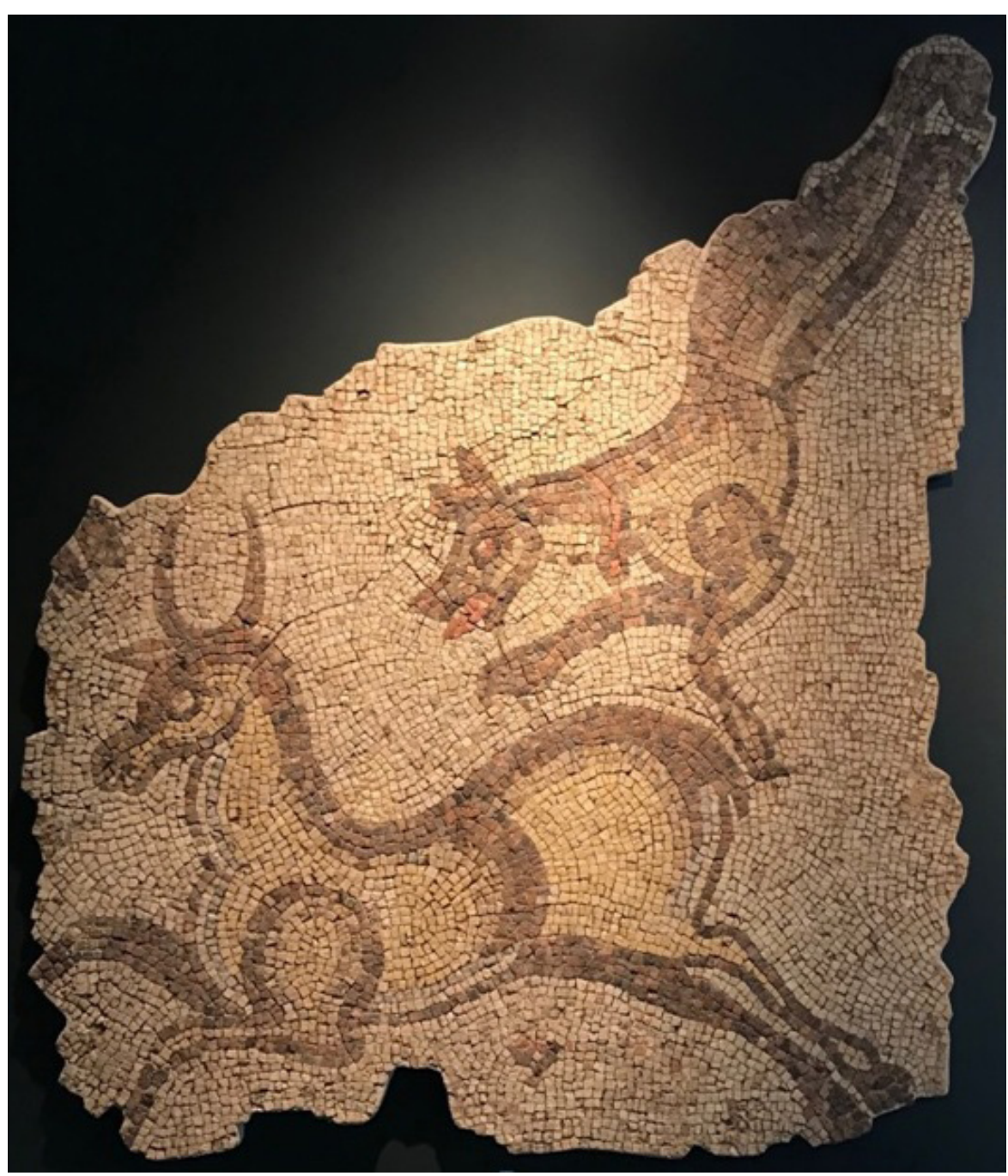

\section{III - 2.1. Description of the Mosaic}

In this fragment of mosaic, a dog chases a running gazelle ${ }^{2}$. The dog, on the verge of jumping onto the gazelle's back, gets ready to grab it. The gazelle positioned in a lateral position, occupies almost the entire width of the fragment. Identifiable by its horns arranged symmetrically in the shape of a lyre, the gazelle has a prominent snout and large wide-open eyes. The body is clearly outlined, with the shoulder and torso groove marked by rows of darker tesserae and the back line alternating with dark and white tesserae. The dog has a similarly outlined body; the tongue coloured in red gives it a fierce appearance, which contrasts with its domesticity marked by the red collar around the neck. The two animals are placed on a clear and neutral background, in which some semis are visible.
Figure 3

Mosaic with hunting scene

(H. $165 \mathrm{~cm} /$ W. $150 \mathrm{~cm})$. CAFMDDS.

2 This mosaic belonged to the collection of S. Thomas Alexander III, from Alexander Gallery Inc. Bud Holland Gallery, Chicago 1980. Purchased from Art Ancient, Jethrow Sverdloff, at the TEFAF 2018. Bühler-Brockhaus Foundation. (Bud C. Holland and Noah Goldowsky opened the HollandGoldowsky Gallery in 1959, focusing on artists from Chicago and the New York School. In August 1961, Holland bought part of his partner and continued the activities of the gallery, which closed in 1991, after his death. 
Figure 4

Mosaic of the Great Palace at Constantinople. Cliché L. Wrench.
The opus tessellatum, inside the bodies, resembles opus vermiculatum, with the tesserae arranged in curved lines and circles. As the technique, as the dimension of the tesserae and the scene presented point to a late period mosaic.

Regarding the scene and the animals in presence, we recall the didactic poem, Cynegetica, whose authorship, although controversial, is attributed to Oppian (from Apamea?), from the $3^{\text {rd }}$ century $\mathrm{AD}$. In the poem, it is possible to read about gazelles: "Everyone knows the splendid herds of the agile gazelles, their beauty, stature and strength [...]" (Calvo Delcán 1990: 98 Op. II v. 315) and about the prototype of the dog that should be trained "to chase gazelles, deer and the hare, fast as a hurricane: its body must be wide and sufficiently strong, its head light and with good eyes, with a dark shine; the mouth must be large, with sharp teeth; small ears, with thin membranes, crowning the head; the body long and the chest strong and broad; the forelegs should be shorter than the hind legs, the tibias straight, slender [...]. As for the colour of the dogs, neither white nor black, because white dogs cannot bear the strength of the snowy winter season and blacks dogs cannot bear the strength of the Sun. Thus, as they are very fast and strong, the best dogs will be those whose colour resembles that of wild beasts, sheep-killing wolves, foxes, leopards or those that have a colour similar to that of Demeter's wheat" (Calvo Delcán 1990: 73-75 Op. I v. 400-415, 427$435)^{3}$. In this mosaic, the representation of the gazelle, beautiful, strong and muscular and, above all, the depiction of the dog seems to correspond to the descriptions made by Oppian.

Due to the fact that we only have a fragment of mosaic, we do not know: if this scene was part of an extended composition of a "hunting scene", with the representation of other animals and humans; if it was isolated in the mosaic decoration set; or if it was represented alongside other scenes of a different nature, such as the mosaic of the Great Palace at Constantinople (part of the collection of the Archaeological Museum in Istanbul) (Fig. 4), in which scenes of predation between real animals coexist with fight scenes between fantastic animals and with rural activities scenes.

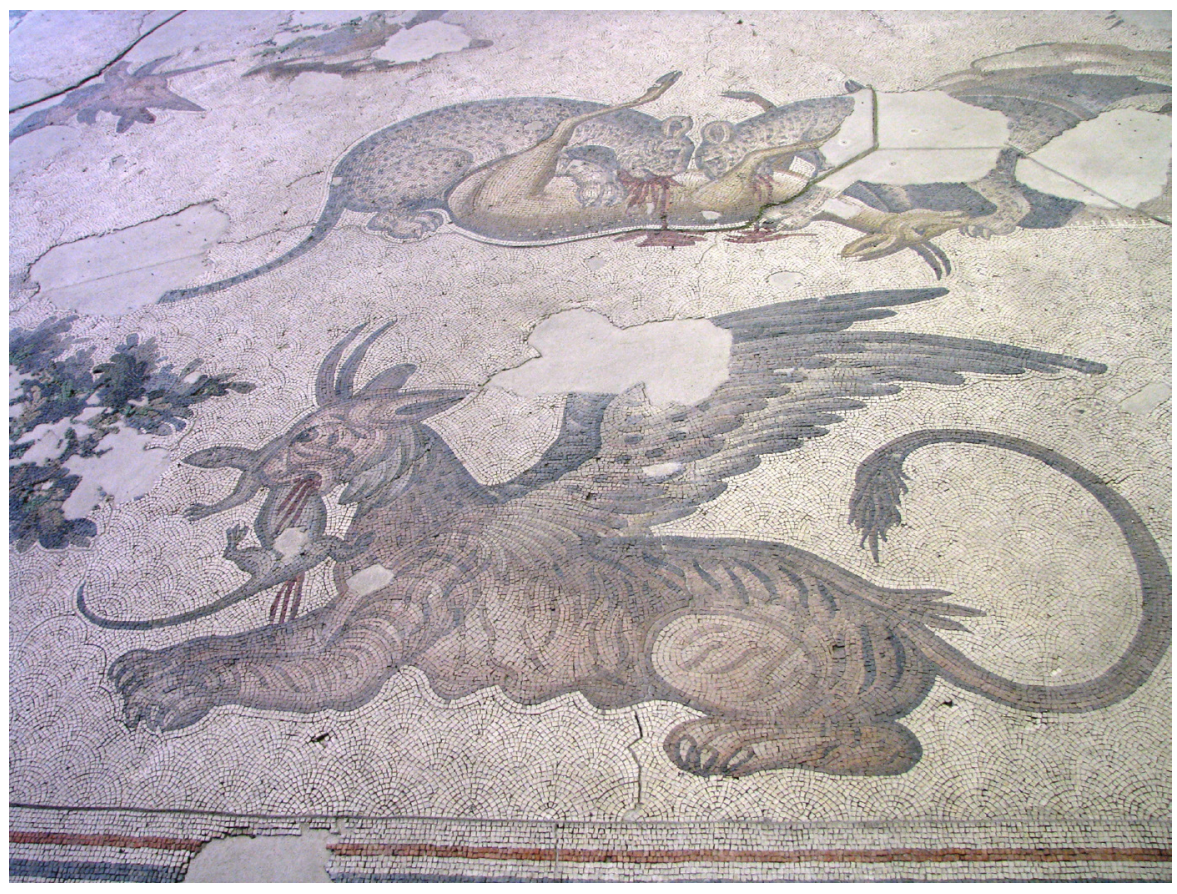

3 Text adapted by us from the Spanish translation. See also Caetano 2017: 173-193, VIII - Cynegethica, including excerpts from the text of Oppian, in the translation of the work quoted here. 


\section{III - 2.2. Some Examples of Mosaics with the Hunting Theme}

The hunting-themed scenes, scenes of amphitheatre, circus and palaestra and scenes of an "unheroic" or "domestic" hunting expanded in the decoration of domestic Roman mosaics since the $3^{\text {rd }}$ century. A very early example, from the last quarter of the $2^{\text {nd }}$ century - first quarter of the $3^{\text {rd }}$ century, is the mosaic of a deer and doe-hunting present at the House of the Fountains, in Conímbriga (Corpus Portugal I: 104-109 $\mathrm{n}^{\circ} 9$ est. 38), in which four horsemen, armed with spears and sticks and followed by their dogs, chase the animals in a continuous circular movement, emphasized by the shape of the medallion in which they are inserted (Fig. 5).

\section{Figure 5}

Mosaic of a deer and doe-hunting scene. House of the Fountains, Conímbriga. Cliché F. Abraços.

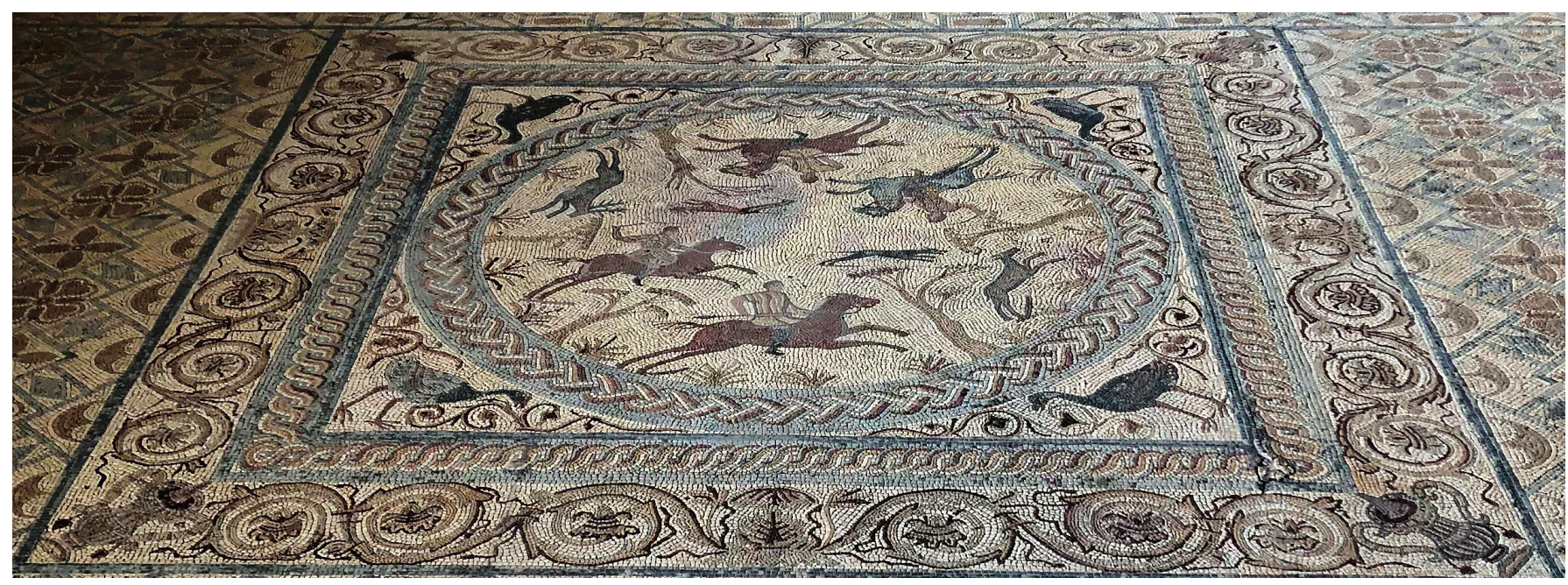

The representations of large hunting scenes of ferocious animals, in which hunters fight with animals on horseback or in close combat, or the animals fight among themselves, can be seen on late mosaics from Eastern and Western Roman Provinces. As a few examples, we can point to the mosaic of Apamea (Mosaic of the Great Hunt at the Governor's Palace, of the late $4^{\text {th }}$ century, in exhibition at the Museum of the Cinquentenary Park in Brussels) (Balty 1995: 354 pl. XXII fig. 1); the mosaic at Carthage, Maison des Chevaux, from the early years of the $4^{\text {th }}$ century in which the theme is affected by the venationes of amphitheatre (Dunbabin 1978: 53 pl. XII figs. 24-25); some 4th century panels (Great Hunt) of the Villa del Casale, in Piazza Armerina, Sicily; on Hispanic mosaics, also from the $4^{\text {th }}$ century, as the mosaic from the eecus of the Villa de La Olmeda (Pedrosa de La Veja, Palencia) (Guardia Pons 1992: 149-156). These examples are depictions of bloody hunts, with scenes of fights between humans and animals. These were authentic battles that in real life could occupy the otium of the Roman elites, among them the military, serving as physical and mental preparation for wars.

It is important to highlight that the animals represented in these scenes, fighting among themselves, will appear on mosaics of a Christian context, namely in basilicas, coexisting peacefully ${ }^{4}$, in a possible evocation of the Messianic kingdom according to Isaiah (Is. 1, 6-8).

4 It appears, however, that many of the mosaics that pave Christian buildings in Northern Syria, dating from the second half of the $5^{\text {th }}$ and $6^{\text {th }}$ century, present scenes of persecution and fight between animals very similar to those represented in the North African mosaics of the $2^{\text {nd }}$ and $3^{\text {rd }}$ centuries. Abdallah 2011 presents a new interpretive proposal for their presence in the naves of basilicas and sanctuaries, corroborating with other authors' idea that images of combat between animals in Syrian mosaics originate from African models of amphitheatre games. These images could recall the Christian persecutions during the Roman period, functioning as metaphors for the martyrs' passion, at a time when their worship had expanded in Northern Syria. 


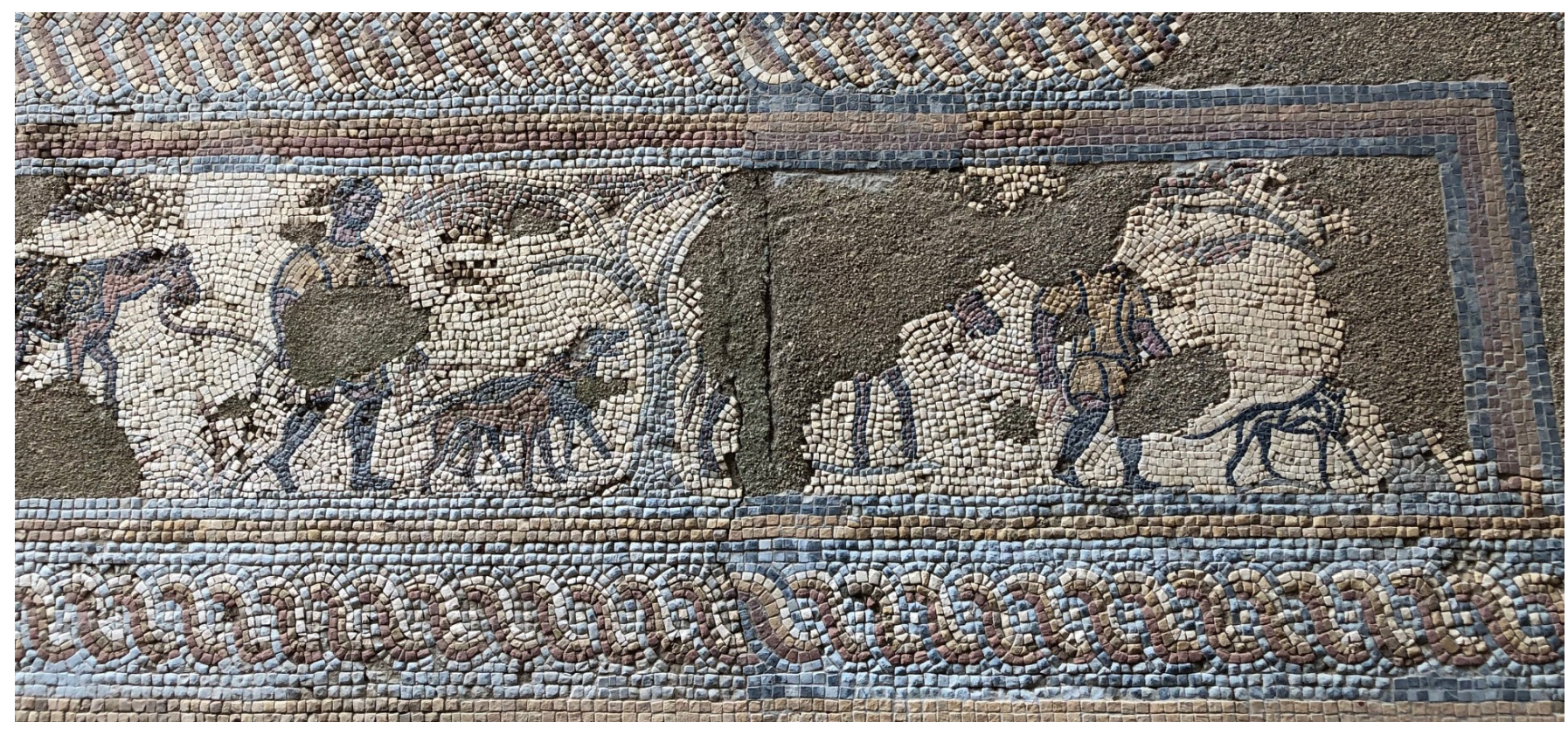

Figure 6

Mosaic of the hunting scene of the "Room of the Auriga" attached to the cecus-triclinium. House of the Fountains, Conímbriga. Cliché F. Abraços.
Another type of hunting that may be designated as "domestic" hunting, sometimes practiced with nets to capture animals, also decorates several late mosaics, among which it is possible to mention the "Hare Hunt" mosaic of ElDjem; the "Little Hunt" mosaic of "Maison des Laberii", at Oudna (Dunbabin 1978 pl. XI fig. 22; pl. XXXIX fig. 101); some of the panels at Villa del Casale, in Piazza Armerina; or the mosaic of a room attached to the secus-triclinium of the House of the Fountains at Conímbriga, dated from the last quarter of the 2nd century - first quarter of the 3rd century (Corpus Portugal I: 117-125 n 11 est. $45-46)^{5}$ (Fig. 6); These representations of hunting scenes, usually practiced at the great Villae, belong to a different conception of hunt, in which the dominus participate, occupying their otium cum dignitate ${ }^{6}$.

Hunting, along with reading, music, and the arts of the Muses are occupations proper of a "virtuous man", which will lead him to achieve, in the Afterlife, an identical satisfaction of the spirit. This conception of hunting as an exercise of uirtus ${ }^{7}$ practiced by the dominus is expressed both in the mosaic of the aforementioned "Room of the Auriga" at Conímbriga, in which the dominus, a victorious auriga in his quadriga, is represented in the central medallion, ascending to the "celestial dome sown with stars" (Corpus Portugal I: 119) and in the mosaic of the Christian Mausoleum of Centcelles Villa, Tarragona. Also on this mosaic, in records overlapping up to the closing of the dome, with the figuration of Good Shepherd and several biblical scenes, the dominus is represented participating in the hunt.

The scene of continuous chase on the mosaic fragment offered to the MDDS, although quite realistic, is represented in an idealized space, with no landscape recording. The type of background decoration with scattered semis or small rosettes is very common in late mosaics from the Roman East, namely from Syria. Some of the Syrian mosaics of Christian context present scenes of chase and fight between animals, whose body postures and volumes are treated in a

5 See also Maciel 1996: 158-160, "Hunting scenes in Conímbriga".

6 Regarding this concept, see Pereira 1990: 381-390.

7 The Latin word: uirtus-uirtutis, according to Cicero, derives from Vir (man). The concept of uirtus, for the Romans, having in its origin the meaning of 'courage', acquires, over time, several connotations. Regarding this concept, see Pereira 1990: 399-409. 
similar way to the gazelle and the dog of the mosaic fragment that is our subject. Among them, we highlight the pavement of the relic chapel of the north church of Houarte, the one from Fa'loul, in which it is possible to observe two small gazelles chased by two dogs and the mosaic of the central nave of the church of Tell Khanzir, with a dog chasing a deer on a background of scattered semis (Abdallah 2018: 209 fig. 2; 240-241 fig. 2) ${ }^{8}$.

In Portugal, we can see on the mosaic of the "hunting scene" of Mértola (Lopes 2003: 102-104 fig. 69) (Fig. 7), from the Byzantine period, similarities with the animals of the mosaic fragment donated to the MDDS, particularly regarding the design of the back of the deer with white and black tesserae and the filling of the body with the tesserae arranged in curved lines, reminding the opus vermiculatum. These aspects will be another contribution to attest to the late execution of the fragment under analysis.

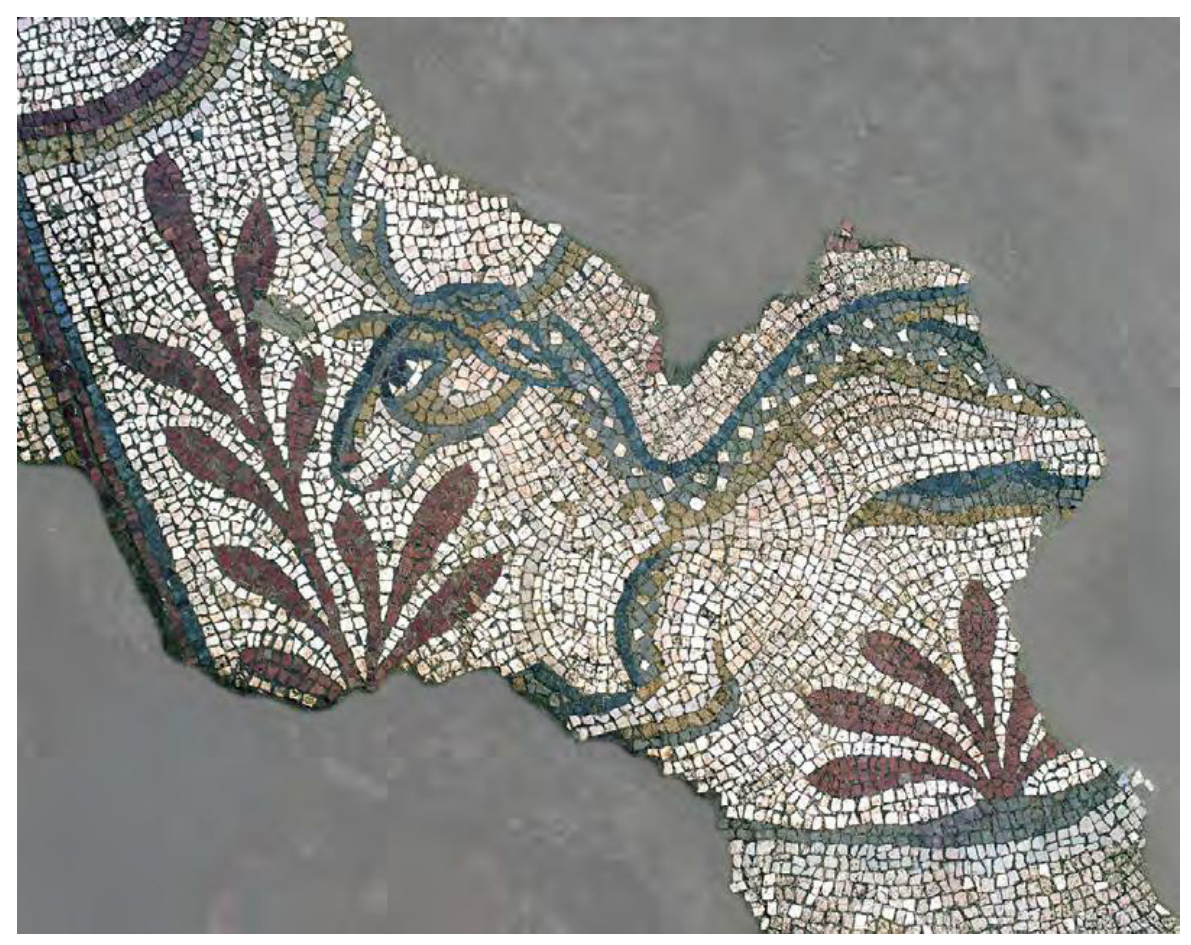

In Late Antiquity, especially in the $3^{\text {rd }}, 4^{\text {th }}$ and $5^{\text {th }}$ centuries, the centres of artistic inspiration and model suppliers were located, mainly, in the Roman Provinces of North Africa and Syria. We may be looking at a mosaic originating from one of these centres or inspired by models from them, although its origin in the Eastern Roman world seems to be the most likely. Due to the parallels found, especially with those coming from Syria and Portugal (Mértola), we propose the $5^{\text {th }}$ century or even the $6^{\text {th }}$ century as the probable chronology for this mosaic, advancing the dating that appears in the exhibition of the piece ( $4^{\text {th }}-5^{\text {th }}$ centuries).

8 We would like to express our gratitude to Komait Abdallah for the information and photos from his book for which we didn't have access to.
Figure 7

Representation of a deer.

Mértola, Portugal. Cliché L. Wrench. 
III - 3. The Mosaic with a Vine-Scroll: Bunches of Grapes, Vine Leaves and Tendrils 9

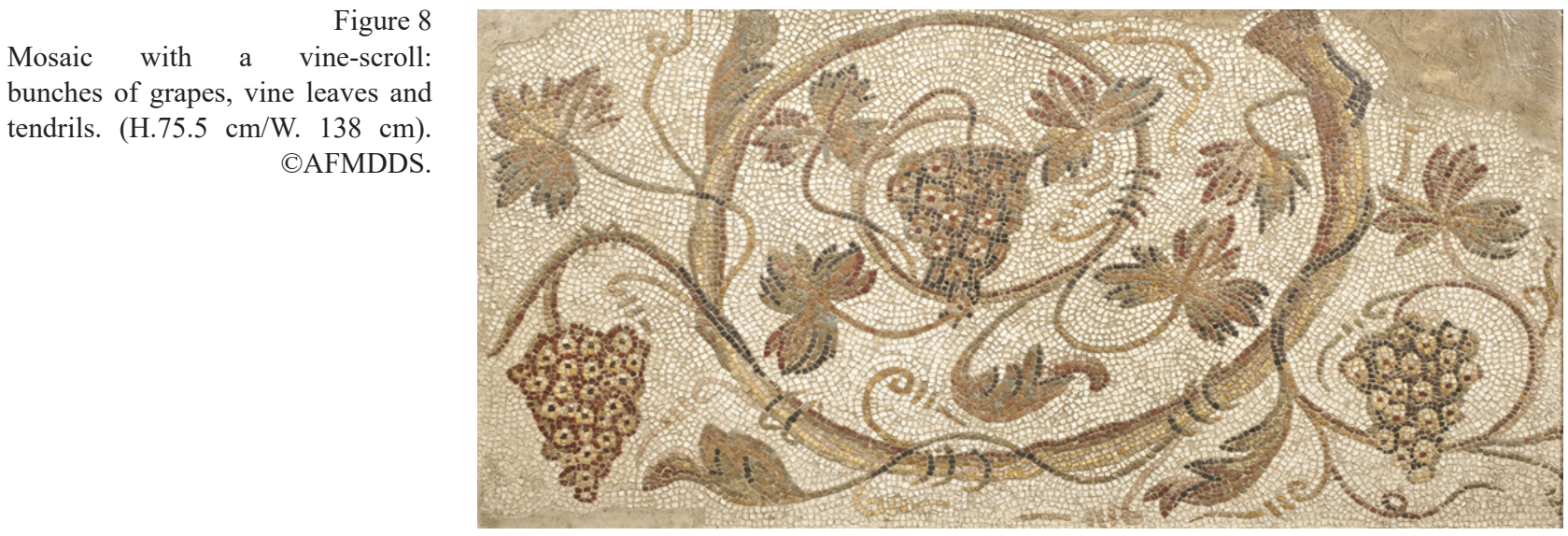

The coppery vine trellis represents autumn and the big bunches display bright berries. The detail of the drawing in which the tessellatum suggests the work vermiculatum, with the vine leaves in frontal and lateral perspectives, the berries with a white tessera in the centre, providing them with volume, and the tendrils that subtly wrap themselves around the trunk are features that point to a mosaic workshop of excellent quality.

Determining the architectural context in which this mosaic is inserted will be an impossible task. If, on one hand, there are mosaics with this theme, either in figured panel frames or expanded to the full length of the mosaic ("carpet vine"), in rooms intended for meals (triclinia), in which the theme will have a more direct and less symbolic relationship with their function, on the other, there are also countless mosaics in which the theme of the vineyard is loaded with symbolism.

The vine was the emblematic plant of Dionysus, a god already celebrated in Mycenaean times, as evidenced by two tablets of Pilos written in linear B, in which his name appears. The worship of this god on the island of Ceos dates back to the $15^{\text {th }}$ century $\mathrm{BC}$ and the occurrence of the Mysteries associated with him is documented from the beginning of the $5^{\text {th }}$ century $\mathrm{BC}$ to the $4^{\text {th }}$ century $\mathrm{AD}$, in an area ranging from the Black Sea to Egypt, from Asia Minor to the South of Italy (Pereira 1992: 11).

The iconography related to this god and its main attributes is one of the most diffused themes from Classical Antiquity to Late Antiquity, namely in mosaic art.

The use of the vine trellis as a layout enlarged on the mosaic pavement is common in Byzancène, but also in Carthage, Oudna and Dougga. The great trend of this decoration seems to be chronologically localised at the end of the $2^{\text {nd }}$ century and in the first half of the $3^{\text {rd }}$, disappearing in the $4^{\text {th }}$ century and reappearing in the $5^{\text {th }}-6^{\text {th }}$ centuries, during which the forms are slightly altered (Ben Abed-Ben Khader 2001: 41).

9 This mosaic belonged to a private collection in Lyon. It was acquired by Charles Ede, London, at the TEFAF 2017. "Charles Ede - Ancient Art" was founded almost 50 years ago and it is recognized as one of the world's leading antique dealers for works of art from ancient Egypt, Greece and the Roman Empire as well as European art. The gallery exhibits at each of the three TEFAF fairs and publishes at least three catalogues annually, including two that coincide with the fairs. 
On the mosaic at Oudna representing millet-stalks and vine scrolls, bunches of grapes hanging from the scrolls and the leaves in frontal and lateral perspectives are rendered quite naturalistically (Dunbabin 1978: pl. LXVII fig. 172). A more schematic draw is on another example of this kind of decoration, on the mosaic of the baths at Themetra (Darmon 2001: 5 fig. 4). Another North African example is one of the mosaics pavement from the "Maison de l'Asinus Nica" at Djemila, a late mosaic with an abstract and geometric treatment of the windings and the leaves slightly cut with a rather clumsy design, the clusters not hanging from the strains, different features in comparison to the mosaics from the Near East (Blanchard-Lemée 1975: 91, 235 pl. XVI).

In the MDDS mosaic fragment, the treatment of the grapevine and all of its elements is quite naturalistic, in opposition of mostly of those North African examples.

Heir to classical art, Christian art appropriates various elements of Dionysian iconography such as the ivy, an evergreen plant that is reborn when cut, the vine, also seasonally reborn, the cantharus, container of the precious liquid, attributing to them the meanings of their ideology. The symbolic latitude of the vintage and its socioeconomic and cultural relevance led to the development of a religious syncretism among various mystical cults linked to fertility, including Dionysism. The powerful confluence of invocations and intercessions made the vine a kind of ecumenical Paradeisos, where the vine assumed itself as a divine and vital arborescence, pronouncing the Christian idea of "Tree of Life". The lush viniculture imaginary proliferated in Christian Catholic churches. In very late chronologies, the gilded carving of the baroque columns is animated by infant angels, as a legacy of the grape picking erotes (Mourão 2016: 218- 219).

In the biblical texts of the Old and New Testaments, there are countless references to the vine, in a clear appropriation of its symbolism, associated with Christ and the Lord's Vineyard, as observed in various decorations of paleo Christian churches. The representation of the stylized vine, with birds, peacocks, vases and shells, covers one of the domes of the Mausoleum of Saint Constance in Rome, dated from the $4^{\text {th }}$ century AD. Also in one of the antechambers of the Baptistery of the church of Zaharani, it is possible to observe vegetal windings, which can be of vines (Chehab 1965: fig. 9).

In the Basilica of S. Demetrius, in Nikopolis, on the pavement of the south wing of the transept, we can see a band with windings of grapevine and vine leafs, which include animals, around a figured panel, in a mosaic dating from the $5^{\text {th }}$ century (Kitzinger 1965: fig. 16).

The pavements from the Maon Synagogue, near Gaza and the Church of Shellae, near the Synagogue, are decorated with the same type of grapevine that appears to have been made by the same Gaza workshop. The same Greco-Roman mosaicists that worked for Jews and Christians left in the church and synagogue a heritage of symbols common to both creeds (Avi-Yonah 1965: 328 figs. 4-5). This type of decoration is also visible in the Justinian Basilica in Sabratha, Libya, as we can see in the details of the figures (Figs. 9a-b).

In Portugal, we can point out the mosaic of Pedras d'El-Rei, Luz de Tavira (Algarve), dated from the 3rd- 4th centuries, and part of the Collection of the National Museum of Archaeology. It is a fragment of mosaic, geometric and figurative, polychrome, with orthogonal composition of octagons formed by a two-strand polychrome guilloche and a frame decorated with grape stems and vine leaves (Fig. 10) (Abraços 1999: 373; Abraços 2005: Annex I: 283-284; Wrench 2005: Est. 26 fig. 2). 
Figures $9 \mathrm{a}-\mathrm{b}$

Details of the pavement mosaic of the Basilica of Sabratha. Clichés F. Abraços.
Figure 10

Mosaic of Pedras d'El-Rei, Luz de Tavira (Portugal). Cliché F. Abraços.

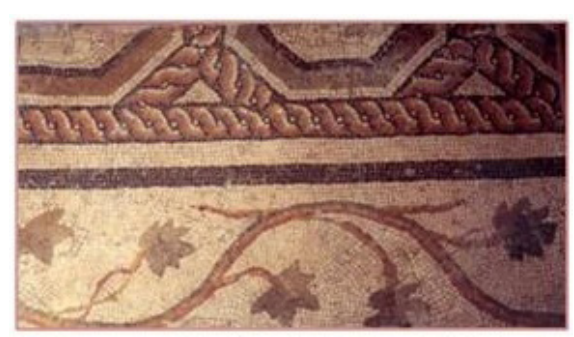

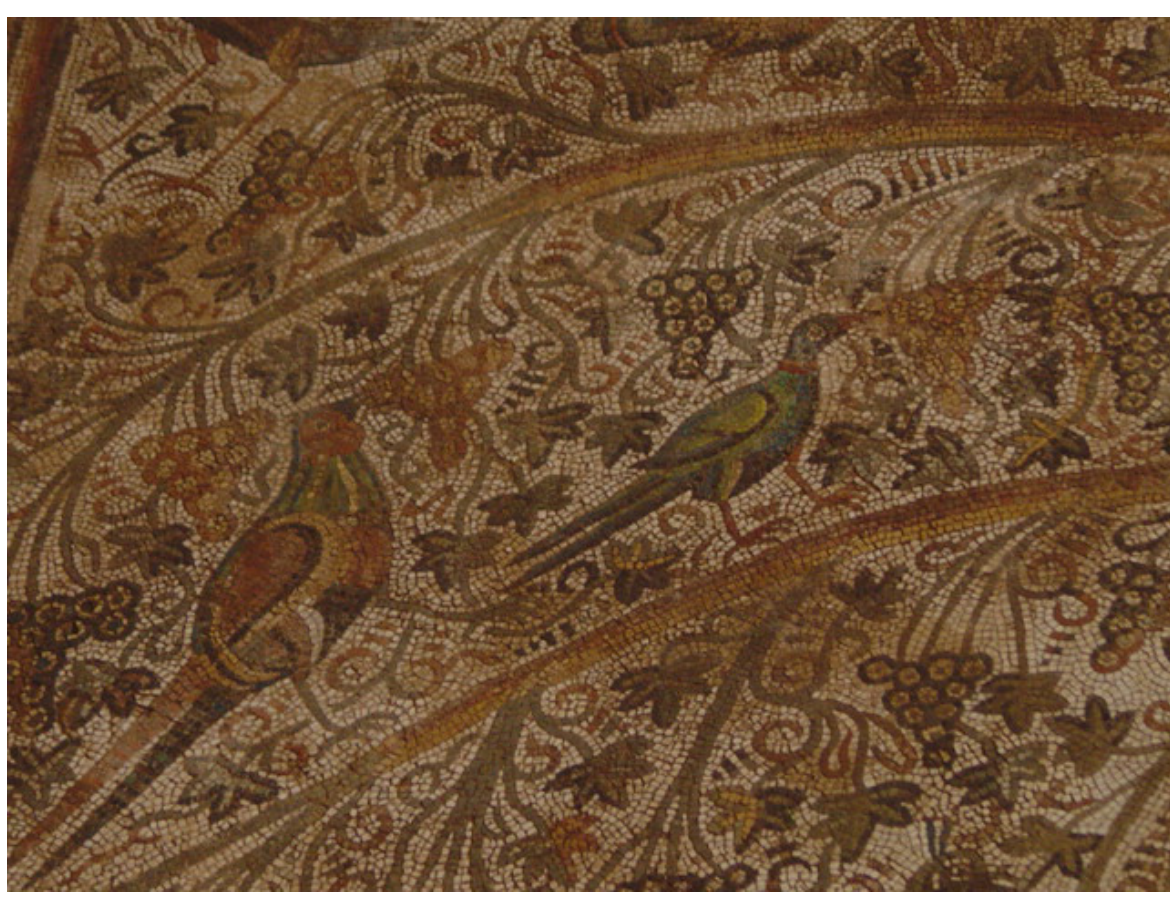

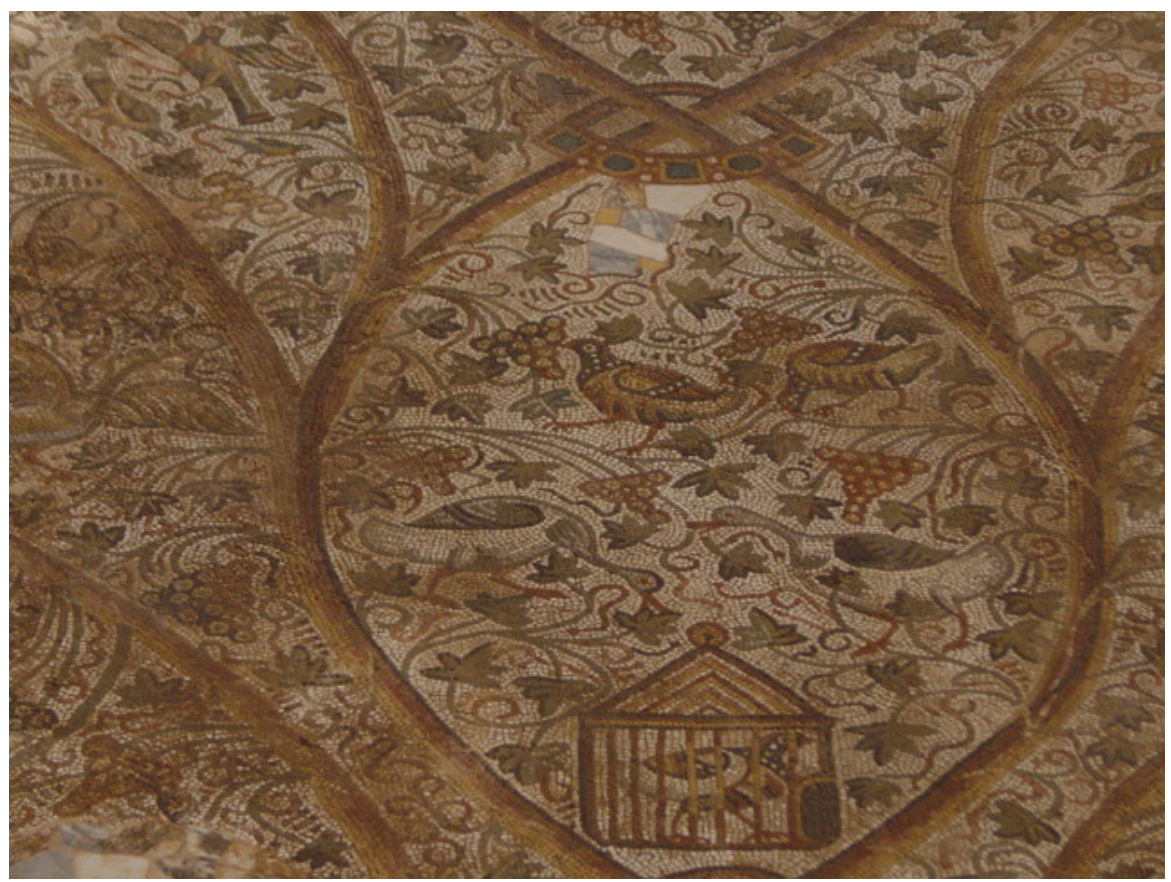

We can state that the three mosaic fragments offered to the MDDS by the collectors Buheler-Brockhaus are of great technical quality, possibly from workshops in the Near East. However, we cannot rule out the hypothesis that an African workshop made the mosaic with the representation of the vinescroll. Regarding the themes presented, the mosaic is distinguished by the representations of Hippodamia and Pelops, in which the eros named as Pothos leads to the interpretation of the scene: the tragic impossibility of union between the couple. As for the hunting (chase) theme and the representation of the vinescroll, we are dealing with themes quite common to mosaics from the Roman world in the East, West and North Africa, used in various architectural contexts and with multiple interpretations. 


\section{Bibliography - Kaynaklar}

Abdallah 2011

Abdallah 2018

Abraços 1999

Abraços 2005

Abraços 2008

Avi-Yonah 1965

Balty 1995

Ben Abed-Ben-Khader 2001

Blanchard-Lemée 1975

Caetano 2017

Calvo Delcán 1990

Chehab 1965

Corpus Portugal I

Darmon 2001

Décor I

Dunbabin 1978

Guardia Pons 1992

Kitzinger 1965

Lancha 1985

Lopes 2003

Maciel 1996

Mourão 2016

Neira Jiménez 2018
K. Abdallah, "Un essai d'interprétation de scènes animalières sur les mosaïques de Syrie du Nord à l'époque byzantine : Les scènes d'affrontement et de poursuite", T. Nicolas - A. Salavert - C. Leduc (eds.), Les images : regards sur les sociétés (en ligne) : 237-249, Paris , Editions de la Sorbonne, 2011 (généré le 21 Septembre 2019). Disponible sur Internet : <http://books.openedition.org/psorbonne/5837>.

K. Abdallah, Les mosaïques romaines et byzantines de Syrie du Nord : La collection du musée de Maarrat alNu'man (Inventaire des mosaïques antiques de Syrie [I.M.A.S.] 3, BAH 213), Beyrouth.

M. de F. Abraços, "Contributo para a História e inventário dos mosaicos romanos”, APort, Série IV, 17, $345-$ 397.

M. de F. Abraços, Para a História da Conservação e Restauro do Mosaico Romano de Portugal, Tese de Doutoramento, Faculdade de Letras, Universidade Nova de Lisboa (Inventário do Mosaico Romano em Portugal: Anexo I - Inventário por Sítios; Anexo II - Catálogo dos Mosaicos Romanos das Colecções de Museus em Portugal).

M. de F. Abraços, "Conservation et restauration des mosaïques romaines au Portugal - Quelques exemples dans les collections de musées", A. Ben Abed - M. Demas - T. Roby (eds.), The 9th Conference of the International Committee for the Conservation of Mosaics, 2005, Lessons learned: reflecting on the Theory and practice of mosaic conservation, Tunisia, Getty Publications, 69-74.

M. Avi- Yonah, "La mosaïque juive dans ses relations avec la mosaïque classique", LMGR I, Colloques Internationaux du CNRS (Paris 29 août-3sept. 1963), Paris, 325-331.

J. Balty, Mosaïques antiques du Proche Orient, Basançon.

A. Ben Abed-Ben-Khader, "Trames Végétalisées à Thuburbo Majus», Recherches Franco-Tunisiennes sur la Mosaïque de l'Afrique Antique, École Française de Rome, 39-45.

M. Blanchard-Lemée, Maisons à Mosaïques du Quartier Central de Djemila (Cuicul), Publié avec le concours du CNRS, Paris.

M. T. Caetano, ANIMALIA QVÆ LACTE ALVNTVR. Mamíferos nos Mosaicos Romanos da Península Ibérica, Lisboa.

C. Calvo Delcán, Opiano - De la caza. De la pesca. Lapidario órfico, Madrid.

M. Chehab, "Les caractéristiques de la mosaïque au Liban", LMGR I, Colloques Internationaux du CNRS (Paris 29 août-3 sept. 1963), Paris, 333-339.

J. M. B. Oleiro (1992), Corpus dos Mosaicos Romanos de Portugal: Conventus Scallabitanus, I, Conímbriga Casa dos Repuxos, Conímbriga, IPM/MMC.

J.-P. Darmon, "Introduction”, M.-P. Raynaud (ed.), Recherches Franco-Tunisiennes sur la mosaïque de l’Afrique Antique. II - Trames Géométriques Végétalisées, École Française de Rome, 1-8.

C. Balmelle - M. Blanchard Lemée - J. Christophe - J.-P. Darmon - A.-M. Guimier Sorbets - H. Lavagne - R.

Prudhomme - H. Stern, Le Décor Géométrique de la Mosaïque Romaine I, Paris, 1985.

K. M. Dunbabin, The Mosaics of Roman North Africa, Studies in Iconography and Patronage, Oxford.

M. Guardia Pons, Los mosaicos de la antiguidad tardia en Hispânia: estudios de iconografía, Barcelona.

E. Kitzinger, "Stylistic developments in pavement mosaics in the Greek East from the Age of Constantine to the Age of Justinian”, LMGR I, Colloques Internationaux du CNRS (Paris 29 août-3 sept. 1963), Paris, 341-352.

J. Lancha, “Cinq fragments de la mosaïque des provinces (Balquîs - Séleucie sur 1'Euphrate) conservés au Museu Nacional de Arqueologia e Etnologia, Lisbonne”, APort, Série IV, 3, 155-176.

V. Lopes, Mértola na Antiguidade Tardia. A topografia histórica da cidade e do seu território nos alvores do Cristianismo, Mértola, Campo Arqueológico de Mértola.

M. J. Maciel, Antiguidade Tardia e Paleocristianismo em Portugal, Lisboa.

C. Mourão, “A vindima nos mosaicos hispano-romanos como expressão de um ecumenismo paradisíaco”, J.

T. García (ed.), Imagens do Paradeisos nos mosaicos da Hispania (Coord. M. Justino Maciel \& Cátia Mourão), Amsterdam, 202-224.

M. L. Neira Jiménez, "On the Interpretation of Pothos in a Mosaic from the Antiquities Market with the Representation of Pélops and Hippodameia”, JMR 11, 149-154. 
Newsletters of IADAA International Association of Dealers in Ancient Art, Sept. and October 2018.

Pereira 1990

M. H. da R. Pereira, Estudos de História da Cultura Clássica, Vol. II, Cultura Romana, 2a edição, Fundação Calouste Gulbenkian, Lisboa.

Pereira 1992

M. H. da R. Pereira, Eurípides - As Bacantes. Introdução, tradução do grego e notas, Edições 70, Lisboa-Rio de Janeiro.

Wrench 2005

L. N. C. Wrench, Decoração vegetalista nos mosaicos portugueses, Lisboa. 
